\title{
The Softskill and Hardskill forms of Tunjuk Ajar Melayu in Nyanyi Panjang Bujang Si Undang Palalawan Society of Riau Province
}

\author{
Erni 1, Ridha Hasnul Ulya 2 \\ DOI: $10.35445 /$ alishlah.v13i3.995
}

\begin{tabular}{l}
\hline Article Info \\
\hline Keywords: \\
Tunjuk aijarmelayu; \\
Soft skill; \\
Hard skill; \\
Nyanyi panjang bujang \\
siundang
\end{tabular}

\begin{abstract}
This research is based on issues of tunjuk ajar inheritance that is no longer exists. The purpose of this study is to reveal and explain the points of tunjuk ajar Melayu Riau. This research is a content analysis research using qualitative descriptive methods. The method in analyzing the data in this research is carried out through three activities, namely: (1) data reduction, (2) data display, and (3) concluding. The results of this study are 4, namely: (1) teaching value related with the faith and piety in Nyanyi Panjang Bujang si Undang can be seen from the indicators of the behaviour of believing in God, doing the commands and leaving God's prohibitions, trustworthiness, sincerity, shame, low heart, and obedience to mother and father; (2) Tunjuk ajar in Nyanyi Panjang Bujang si Undang is reflected in the behaviour of saying as what it is, acting based on truth, and being responsible; (3) the intelligence character found in Nyanyi Panjang Bujang si Undang includes behavioural indicators, such as: directed, logical, and analytical thinking, being able to find solutions, careful, far-sighted, and the priority to study; and (4) nationality values in tunjuk ajar include behavioural indicators relating to unity and integrity, cooperation, rights and property, consensus agreement, and obedience to leaders.
\end{abstract}

Kata kunci:

Tunjukajarmelayu;

Soft skill;

Hard skill;

Abstrak

Nyanyi panjang bujang siundang

Penelitian ini dilatarbelakangi oleh isu-isu tunjuk ajar sebagai warisan yang sudah tidak diterapkan oleh masyarakat. Tujuan dari penelitian ini adalah untuk mengungkapkan dan menjelaskan poin-poin tunjuk ajar Melayu Riau. Penelitian ini merupakan penelitian analisis isi dengan menggunakan metode deskriptif kualitatif. Metode dalam menganalisis data dalam penelitian ini dilakukan melalui tiga kegiatan, yaitu: (1) reduksi data, (2) display data, dan (3) penarikan kesimpulan. Hasil penelitian ini ada 4, yaitu: (1) nilai ajaran yang berkaitan dengan keimanan dan ketakwaan dalam Nyanyi Panjang Bujang si Undang dapat dilihat dari indikator perilaku beriman kepada Tuhan, melaksanakan perintah dan meninggalkan larangan Tuhan, amanah, ketulusan, rasa malu, rendah hati, dan ketaatan kepada ibu dan ayah; (2) Tunjuk ajar dalam Nyanyi Panjang Bujang si Undang tercermin dalam perilaku berkata apa adanya, bertindak atas dasar kebenaran, dan bertanggung jawab; (3) karakter kecerdasan yang terdapat dalam Nyanyi Panjang Bujang si Undang meliputi indikator perilaku, seperti: berpikir terarah, logis, dan analitis, mampu menemukan solusi, cermat, berpandangan jauh ke depan, dan mengutamakan belajar; dan (4) nilai kebangsaan dalam tunjuk ajar meliputi indikator perilaku yang berkaitan dengan persatuan dan kesatuan, gotong royong, hak dan milik, kesepakatan musyawarah, dan ketaatan kepada pemimpin.

\footnotetext{
${ }^{1}$ Un iv ersitas Islam Riau, Pekanbaru, Indonesia

Email: erni@edu.uir.ac.id@gmail.com

2 Universitas Negeri Padang, Padang, In donesia

Em ail: ridhasnulya.unp@gmail.com

Vol.13(3) December, 2021

Received: August 21, 2021; Received in revised form: September 17, 2021; Accepted: October 29, 2021; Available online: October 31, 2021

Th is is an open access article under a Creative Com mons Attribution-NonCom mer cial-ShareAlike 4.0 In ternational License
} 


\section{INTRODUCTION}

Ulya (2019) states that the broad scope of local wisdom can include: thoughts, attitudes, language actions, arts, and literature. Efforts to develop local wisdom will not be carried out properly without optimal community participation. The participation of various community elements in taking the initiative and becoming the organizer of the education program is an invaluable contribution and needs to get attention and be appreciated (Ulya, 2019; Ulya, 2018; Wardani, 2018; Dagnall, 2007).

Nigel Phillips (1981) has done previous research on oral tradition, researching oral traditions in the Lima Puluh Regency of West Sumatra Province, with the title Si Jobang: Sung Narrative Poetry of West Sumatra. From the data description of cultural values, several moral values are expressed, such as hospitality, tactics, respect and obedience to the king, justice, patience and endurance, humility, honesty, respect for others, trust, and responsibility. In addition, Thomas Frans, in 2009, researched the Traditions of Peladalam Tradition in the Ambon Community. This study aims to describe the Pela tradition in Ambon society. To achieve this goal, a description of four aspects is carried out, namely (1) Pela tradition discourse structure, (2) message disclosure strategy in Pela tradition discourse, (3) Pela tradition discourse function, and (4) values contained in tradition discourse pela.

Furthermore, Rachmawati (2009) examined oral literature with the title Larvul Ngabal: Oral Kei Tradition. This research was conducted to describe the story of Larval Ngabal, specifically regarding: (1) the forms of the Larvul Ngabal story based on its contents, (2) the meaning of the story of Larvul Ngabal, which links human relationships with something outside of itself that is vertical or horizontal, and circular -harmonious; and the function of Larvul Ngabal's story which is considered capable of influencing and directing the behaviour of Kei people, (3) the retention strategy of Larvul Ngabal's story based on normative and relative aspects. Based on these studies, it can be understood that the tendency of research topics in oral literature prioritizes aspects of the objective literary paradigm, namely the literary structure itself. However, the difference and renewal in this study emphasize aspects of developing local wisdom values in Malay Tunjuk Ajarwhich is contained in Nyanyi Panjang Bujang Si Undang (starting now abbreviated as NPBSU).

The morale of the life forms of the nation and state of society lately has led to forms of sociocultural behaviour that is not of national character. This made the Indonesian government realize the need for national character education. In order to overcome the moral degradation of the nation, currently, the Indonesian government is intensively implementing character education in educational institutions, starting from the early level, elementary schools, secondary schools, to universities. Through character education implemented in educational institutions, it is expected that the crisis of character degradation or morality of this nation's children can be resolved soon. More than that, it is hoped that generations of people will be born with a height of character or character in the future. Culture consists of knowledge, custom, principal, habit, hope, attitude, belief and the way of thinking that have been agreed as the character or identity of the group (Ulya, 2018; Dean, 2013; Mizkat, 2018). Erni (2018) states that there are some reasons why this research needs to be done. First, one of the government's programs, president Jokowi, is a mental revolution. This program needs to be responded wisely since the condition of Indonesian society is at the level of significant chaos that affects the faded of society's self-actualization.

Character education or character education in the Riau Malay community, morals and morals are known by pointing Malay teaching. The instructions referred to here are all kinds of advice, guidance, advice, mandate, teaching, and role models beneficial to human life in the broadest sense. Guidance teaches people to take the straight path and be blessed by Allah, whose blessings are to save people in life in this world and the hereafter. Guidelines for Tunjuk Ajar are all kinds of advice, guidance, mandate, teaching, and examples that benefit human life in the broadest sense (Effendy, 2004). In order to bring about people who are virtuous, virtuous, intelligent, and 
praiseworthy, Malay people pass their teachings in a variety of ways, both through verbal expressions and through examples and examples. Oral inheritance can be done by using oral literature such as rhymes, poems, folktales, expressions, sayings, thimbles, parables, and so on. Inheritance through examples and examples is done by giving examples of behaviour, behaviour, and commendable action.

One aspect of the novelty of this research is that not many researchers have developed the values of character education in oral literature, especially the Nyanyian Panjang of Bujang Si Undang. In addition, previous research has not accommodated the integration of oral literature from local wisdom into issues and materials in learning literature in schools. Literature learning activities have strong relevance to the government's mission of strengthening character education. The study of literature itself is sometimes given the impression of learning morals and values. In addition to internalizing values, students are also guided to have moral reasoning about the concept of good and bad. According to Tomlison and Carol (2002), children's literature helps children to have moral reasons in formulating the concept of good and bad. In this case, students can interpret the experiences of the characters in the story who are faced with choosing situations with all the consequences. Through Nyanyian Panjang of Bujang Si Undang, children can learn various values in society, such as honesty, courage, ingenuity, happiness, and others.

\section{METHOD}

This research is a type of content analysis research. The data in this study are in the form of words, phrases, clauses, sentences, whose interpretations are believed to contain Malay Tunjuk Ajarpoint values. The data source of this research is the text of Nyanyi Panjang Bujang Si Undang, which has been transcribed and documented in printed book form. Data collection techniques in this study were carried out using documentation. Furthermore, at the stage of analyzing the research data, the data presentation and discussion stages are carried out, presented simultaneously in one integrated presentation. Next, the points of Malay Tunjuk Ajar were disclosed in the story structure of Bujang Si Undang. In this case, the integration of several methods, namely content analysis, structural, and interpretation, will be sought as far as possible to display it in an integrated manner. The researcher determined the text of Singan Panjang Bujang Si Undang as the data source because no previous researcher had explored the teaching values in the text. In addition, the text of Long Song of Bujang Si Undang is one of the oral texts related to historical literature that can be used as knowledge for current and future generations.

Furthermore, to obtain data on Malay teaching and to learn in the text of Nyanyian Panjang Bujang Si Undang, the researcher used a data inventory format adapted from Effendy's Tenas theory regarding the classification Tunjuk Ajar Melayu. Researchers classify the types of Tunjuk Ajar Melayu used in data analysis based on the classification of Tenas Effendy. However, the researcher classifies teaching and learning into four Tunjuk Ajar Melayu because the Tunjuk Ajar Melayu indicators described by Tenas Effendy have many similarities and overlaps. The four Tunjuk Ajar Melayu are meant, namely: (1) faith and devotion, (2) honesty, (3) intelligence, and (4) nationalism.

\section{FINDINGS AND DISCUSSION}

Appoint the teachings of Nyanyi Panjang Bujang Si Undang (in the future abbreviated as NPBSU) covering six aspects, namely (1) point to the teachings of faith and be devoted to God, (2) point to honest teaching, (3) point to philosophical teaching and (4) point to national teaching. A full explanation of the discussion of the four Tunjuk Ajar can be seen from the following description. 


\section{The Softskill Form Tunjuk Ajar Faith and Devotion to God in NPBSU}

Pointing at the teachings of the faith and devotion to God Almighty is a Tunjuk Ajar that involves a person's thoughts, words, and actions who is constantly sought based on the religious values and religious teachings. According to Samani (2013:122), faith and devotion are all things that are highly related to the existence of God the Creator by acting according to His commands and Tunjuk Ajars and avoiding all its prohibitions. Appoint the teachings of faith and piety can be observed from behavioural indicators, such as trust in God Almighty, carry ing out commands and leaving God's prohibitions, trustworthy, sincere, ashamed, humble, and obedient to the motherfather.

The results of the data analysis showed that the teachings in Nyanyi Panjang Bujang Si Undang with a focus on faith and piety were drawn from the thoughts, words and deeds of the characters by the values of belief in God. It is essential to carry out commands away from prohibition, trustworthiness, sincerity, shame, humility, humility, and obedience to the ladies and gentlemen. In NPBSU holding firm, the mandate is an attitude that dominates the Tunjuk Ajar of faith and devotion. Allah commands human beings to convey the mandate to those entitled to receive it (QS. an-Nisâ [4]: 58). The obedience of the Buyung Si Kubin figure in holding the mandate and his mother, who always gives the mandate to her two children, reflects the attitude of the people who hold the mandate firmly. This can be seen from the attitude of Kubin, who always reminded his brother of his mother's mandate when he would leave. Every time he saw his brother Bujang Si Undang's attitude that was quick to deal with problems.

Obedience to mother and father is a priority in the life of the Petalangan Malays. There is a statement for parents who say that whoever obeys his parents will survive in the world and the hereafter. Furthermore, the research findings show that in the transcription of Nyanyi Panjang Bujang Si Undang, several strands were found containing the values of Tunjuk Ajarobedience to mothers and fathers. Some strands prevalent in Malay poetry tell a lot about the ugliness of the ungodly child whose life ends in disaster and misfortune and the story of the glory of a child who is obedient to his parents.

The last thing discussed regarding the Tunjuk Ajar of faith and devotion to God in NPBSU is sincerity. Sincerity is related to what humans do in their lives. In the Koran (98: 5), sincerity means purifying the observance shown by living searching for Allah's pleasure (Subur, 2015: 242). The nature of sincerity becomes a priority in the life of the Petalangan Malays. Petalangan people believe that by being sincere, every job will become a good deed blessed by God. The nature of sincerity, willingness to sacrifice and a sense of social solidarity can produce true brotherhood. For Petalangan Malays, helping fellow believers has become an obligation. They help with the awareness that other people are relatives, friends, or relatives. Brotherhood, social customs, or related customs oblige Petalangan Malays to do benevolence benevolently and sacrifice anything voluntarily.

In the regular expression, it is said, who obeys the religion of Islam, the grudges his hatred forbidden or who faithfully hold the custom, his revenge is unbearable. This can be seen when $\mathrm{Si}$ Kubin convinced his brother not to give a punishment commensurate with what he had done to him. He did not feel vengeful to the Datuk nanours. In daily life, the Petalangan Malays maintain harmony in the community with a broad-breasted, forgiving, generous, and tolerant to keep the emergence of seeds of mutual friendship. Therefore, any differences of opinion or disputes should be quickly muted by forgiving each other (Effendy, 2004). 


\section{The Softskill Form Tunjuk Ajar Honesty in NPBSU}

Honest is a behaviour based on efforts to make himself a person who can always be trusted in the words, actions, and work, both towards themselves and other parties. The results of the data analysis show that the Tunjuk Ajar of honesty in Nyamyi Panjang Bujang Si Undang is drawn from the indicators of behaviour that says what it is, acts based on truth, and is responsible for what is practised by the characters. In the Bujang Si Undang story, Ajo Tan Gadih always answers the Bujang Si Undang's questions honestly by reality. Bujang Si Undang questioned the letter of the button he found in the chest. The letter notes the story of his uncle's trip to go abroad, who never returned. Ajo Tan Gadi said that the truth was that the truth would open up opportunities for his son Si Undang to beg to go abroad to look for his uncle. This is what worries Ajo Tan Gadi very much. The character of Kubin also shows the behaviour of saying what it is. On various occasions, the Si Kubin character always shows honest behaviour with indicators saying what they are. When Bujang the Undang asks for the cause of its occurrence, Si Kubin explains what it is without adding or reducing the reality.

In NPBSU, there is a message of Tunjuk Ajar about attitudes that prioritize doing based on truth. The values of justice and truth are found in Nyanyi Panjang Bujang Si Undang. For Petalangan Malays, justice and truth are the primary keys in upholding good fortune and virtue, lifting dignity and dignity, and establishing sovereignty and authority (Effendy, 2004). Justice and truth are references to one's life, government and life attitude. Bujang Si Undang delivered the Nine Laws to the Four Datuk Dat to enforce the law fairly and correctly. It was intended to ask for justice to Datuk nanours for the death of Bujang Si Undang's younger brother named Si Kubin. Dibaye semui or atui lines, Sobanyak kosik on the beach, Sobanyak obuk on kopalo is a form of justice and truth handed down by the characters. These words have the content of justice because when Bujang the Undang found out about the irregularities of his brother's death, he still decided to remind Datuk Nanempat about the law that must be obeyed so that it could be worth justice. Even though he has his own country and remembers his hometown, he still has to be held accountable fairly to rule the kingdom he leads.

Tunjuk Ajar aims to instil values in students to have a whole, integrated, and balanced character. Students who have character values will use all their knowledge, skills, and emotio ns in solving problems encountered. The purpose of integrating Tunjuk Ajar values in formal education is to strengthen and develop life values that are considered essential and improve the behaviour of students who are deemed incompatible with life values (Kesuma et al., 2011:137).

\section{The Hard skill Form Tunjuk Ajar Intelligence in NPBSU}

Smart is thinking and doing things in reality or logic to produce new or most recent ways or results from what they already have. The results of the data analysis show that the Tunjuk Ajar demonstration in Nyanyi Panjang Bujang Si Undang with a focus on intelligent characters is drawn virtues of demanding knowledge and looking far ahead. The NPBSU Tunjuk Ajar guide also prioritizes recommendations and directives so that community members learn diligently and draw knowledge and technology, both for the welfare of life in the world and those related to the afterlife. A great sense of curiosity from the characters so that without being reluctant to find out any information and from anyone about the existence of the inheritance. The virtue of a character who dares to leave his country to add and apply the knowledge he has to search for his lost treasures. This is intended to increase the knowledge of the figure because it will face significant challenges in other countries so that it shows its curiosity to learn and gain a lot of knowledge (Effendy, 2004; Maskar, 2009).

The attitude held by Bujang Si Undang is shown when he is about to decide to go abroad. He believes that his knowledge will not increase if only in the village so that the mind wants to try to migrate to other countries. Looking far ahead and by remembering the fate of the children and 
grandchildren in the future, it is hoped that ideas will emerge that can ensure the survival of their children and grandchildren to make the community aware of themselves (Effendy, 2004). In addition, there are indications of clever use of the time from the character that can be guided. The goodness of people who are good at using time is compared with people who waste time so that the community can set an example of what is good and what is bad (Effendy, 2004). In the traditional expression, it is said, abstinence from Petalangan Malay wastes time. Who likes to waste time, his life's address will perish. There is value in utilizing time in Nyanyi Panjang Bujang Si Undang. The string tells when Bujang Si Undang was permitted to go abroad by his mother. His mother used a few days (7 days) to negotiate the departure of Si Undang with the village headman.

Carefulness is a laudable quality in the life of the Petalangan Malays. They can calculate various possibilities so that life and the economy can run smoothly and sufficient. Thanks to Bujang Si Undang's carefulness, he did not believe that his younger brother had died of a long fever or stomachache, so he assumed that someone had killed his brother. A careful attitude encourages them to be careful and calculating in their lives. With a caring attitude, they can do, design, and try well and correctly. Accuracy usually causes someone not to act arbitrarily, not to do without knowledge, without consideration, and so on (Effendy, 2004).

Based on the explanation above, it can be understood that the moral elements and values contained in a literary text become a vehicle for catharsis, namely the enlightenment of the soul or awareness of the soul to social situations and self-introspection. This catharsis vehicle will be felt by children when children are guided to live and analyze the moral messages and values contained in literary works. Internalizing the values contained in literary works can guide students to have emotional intelligence by understanding the feelings of others (Norton, 2010; Auciello, 2006). Emotional intelligence itself is an inseparable part of the character education process.

\section{The Softskill Form Tumjuk Ajar Nationalist NPBSU}

The results showed that there were national Tunjuk Ajar standards in NPBSU. The national Tunjuk Ajar value is the Tunjuk Ajar relating to the spirit of nationalism or one's devotion to the nation and country. The results showed that there are types of national Tunjuk Ajar indicates contained in NPBSU. Tunjuk Ajar's nationality consists of behavioural indicators: unity and integrity, cooperation, rights and property, consensus agreement, and obedience to leaders. In the NPBSU story, the Bujang Si Undang is a figure who upholds the spirit of nationalism towards his nation and country. He has sacrificed himself to seek back dondang the inheritance of his people who have been lost. The desire to maintain property rights and uphold the fervour of his people is so inherent in him that he is willing to leave the older man and sail the vast seas to reclaim the rights of his people. His high courage makes this story more heroic, with various adventures in its path.

The research results on NPBSU, Datuk Nan Berempat figures are examples of leaders who cannot be made for the local community. He is known as the king of persecution and cannot act fairly in deciding cases. This can be seen in his careless actions to kill Buyung Si Kubin without listening to an explanation first. A country or place controlled by a wrongdoing leader will also create an atmosphere in society that is not conducive. The condition of the community led by Datuk Rajo Nan Ampek is a society that is not trustworthy, treasonous and a liar. This was seen when Buyung Si Kubin was about to kill the Sikotimuno snake. The whole community promised to tell the truth to Datuk Rajo Nan Ampek that he entered the Datuk Mambang Kuning booth to kill snakes in the presence of many people. However, when Datuk Rajo Nan Ampek returned, the country's people cried to say that Bujang Si Kubin had presumptuously entered his grandfather's room. This made the progenitor angry and told the commander to pick up the Kubin to stand trial. The betrayal committed by the community has taken the lives of innocent people. 
The tyrannical power of the king usually does not last long. His leadership will collapse when other characters appear with good character. In NPBSU, for example, the figure of Datuk Nan Berempat was replaced by Bujang Si Undang. Bujang Si Undang was appointed as the king in place of Datuk Nan Berempat because of his honesty and courage to uphold the truth so that there was a high level of trust from the people to convert him to be a king. If explored more deeply, Bujang Si Undang is not a person who comes from that country, but because of his ability, he is trusted by the country's inhabitants to become a king.

This is by the opinion of Lickona $(1991 ; 2013)$, which states that a person will be easier and more successful in facing all kinds of life challenges, including challenges to succeed academically (Muslich, 2011: 151). In addition, the mandate of Law Number 20 the Year 2003 concerning the National Education System in Article 3 confirms that national education functions to develop capabilities and shape the character and dignity of a nation with dignity in the context of the intellectual life of the nation, aiming at developing the potential of students to become human beings have faith and piety to God Almighty, noble, healthy, knowledgeable, capable, creative, independent, and become citizens of a democratic and responsible country.

The content of national teaching can also be seen from the indicators of obedience to the leader. Obedience to the leader can be seen from the respectful attitude of Bujang Si Undang. This respect was shown by offerings and sayings of mercy from Bujang Si Undang when he had just arrived in an overseas country and wanted to inquire about the whereabouts of Dondang Panjang. Bujang Si Undang showed respect by offering to respect and honour Datuk Nan Berempat as the leader in the country. Bujang Si Undang can represent a people who are very obedient and respectful to a leader. For the Petalangan Malay community, a leader is a role model that must be followed, obeyed, and respected. In this context, Bujang Si Undang has carried out his obligations as a Petalangan Malay who respects his leader. Even though he wanted to ask the king for justice, he kept reminding himself that he was just a commoner who needed to uphold the king's dignity and acknowledge the king's greatness.

The NPBSU is also loaded with national teaching values with indicators of deliberation and consensus. This is following the custom of the Petalangan people, who make deliberation and consensus as to the basis of their custom. The elders said, upholding adat because of consensus, upholding luck because of this reference deliberation caused them to respect significantly, uphold, and glorify and reach consensus in their daily lives. Whether personal, family, or public, the form of design and work must be discussed, at least in a limited environment. They realized that without deliberation, apart from being considered an insult to customs, the design work would also experience obstacles and be challenging to carry out.

\section{CONCLUSION}

Tunjuk Ajar value related to faith and piety in Nyanyi Panjang Bujang Si Undang can be seen from the indicators of belief in God, do the commands and leave God's prohibitions, trust, sincerity, shame, humility, and obedience to father. The Tunjuk Ajar value in Nyanyi Panjang Bujang Si Undang also emphasizes the value of honesty which is reflected in saying what it is, acting based on truth, and being responsible. In addition, the dominant intelligence pointing value in Nyanyi Panjang Bujang Si Undang is reflected in indicators of direct, logical, and analytical thinking so that it teaches humans not to be emotional and keep thinking directed, logical, and analytical when encountering a problem. Finally, the national Tunjuk Ajar values are strong enough values inherent in the Nyanyi Panjang Bujang Si Undang story include behavioural indicators relating to unity and integrity, cooperation, rights and property, consensus agreement, and obedience to leaders. 


\section{REFERENCES}

Auciello, J. (2006). Teaching for Character: Education for English Teachers. Journal of Education, $187(3), 57-69$.

Dagnall, Neil, et al. (2007). Superstitions Belief-Negative and Positive Superstitions and Psychology Functioning. European Journal of Parapsychology. 22 (2), 121-137.

Dean, Fenella. (2013). Superstitions is an Urban Contemporary Community. The Student Researcher Journal. 2 (2), 59-77.

Effendy, Tenas. (2014). Tunjuk Ajar Orang Melayu (Butir-butir Budaya Melayu Riau). Yogyakarta: Balai Kajian dan Pengembangan Budaya Melayu.

Erni, E., Hasanuddin, W. S., Thahar, H. E., \& Asri, Y. (2018, April). Nyanyian PanjangBujang Si Undang as oral tradition in Melayu Ethnic; an alternative approach for mental revolution. In International Conferences on Educational, Social Sciences and Technology (pp. 430436). Fakultas Ilmu Pendidikan UNP.

Frans, Thomas. (2009). Wacana Tradisi Pela dalam Masyarakat Ambon. Malang: Program Pascasarjana Universitas Negeri Malang.

Katilmis, A., dkk. (2011). Efficiency of Social Studies Integrated Character Education Program. Educational Sciences: Theory \& Practice 11(2), 854-59.

Kesuma, Dharma, Cepi Triatna, dan Johar Permana. (2011). Pendidikan Karakter: Kajian Teori dan Praktik di Sekolah. Bandung: PT Remaja Rosdakarya.

Lickona, Thomas. (1991). Educating for Character: How Our Schools Can Teach Respect and Responsibility. NewYork: Bantam Books.

Lickona, Thomas. (2013). Educating for Character: Mendidik untuk Membentuk Karakter. Jakarta:Bumi Aksara.

Maskar, Herman. (2009). Nyanyi Panjang Sutan Pominggie. Pekanbaru: Gurindam Press.

Mizkat, Eva. (2018). Karakteristik Tokoh-Tokoh dalam Cerpen Anak Si Gigi Kelinci dan Behel Karya: Wahyu Indriyati. Jurnal Dialog, 6 (2), 1-12.

Muslich, Masnur. (2011). Pendidikan Karakter Menjawab Tantangan Krisis Multidimensional. Jakarta: Bumi Aksara.

Norton, Donna E. (2010). Through the Eyes of a Child: An Introduction to Children's Literature. Boston: Prentice Hall.

Rachmawati, Patty. (2009). Larvul Ngabal: Tradisi Lisan Kei. Malang: Program Pascasarjana Universitas Negeri Malang.

Subur. (2015). Pembelajaran Nilai Moral Berbasis Kisah. Yogyakarta: Kalimedia.

Ulya, R. H., Thahar, H. E., Asri, Y., \& Agustina, A. (2018, April). Cultural manifestation in superstition of Minangkabau society. In International Conferences on Educational, Social Sciences and Technology (pp. 422-429). Fakultas Ilmu Pendidikan UNP.

Ulya, R. H. (2019). Dimensi Keteraturan Sosial Wanita Hamil dalam Gamitan Superstisi Kubuang Tigo Baleh. Kafaah: Journal of Gender Studies, 8(2), 183-196.

Ulya, R. H. (2018). Reinterpretation of Ethic Value in Minangkabau's Superstition. TELL-US Journal, 4(1), 47-57.

Wardani, Y. F. (2018). Nilai pendidikan karakter dalam novel Rindu karangan Tere Liye: Tinjauan psikologi karakter. AKSIS: Jurnal Pendidikan Bahasa dan Sastra Indonesia, 2(2), 246-274. 